\title{
Pengaruh Jenis Pelarut Dan Rasio Bahan Dengan Pelarut Pada Metode Ultrasonikasi Terhadap Aktivitas Antioksidan Ekstrak Daun Beluntas (Pluchea indica Less)
}

\section{The Effect of Type of Solvent and the Ratio of Material to the Solvent by the Ultrasonication Method on Antiokxidant Activity of Beluntas Leaf Extract (Pluchea indica Less)}

\author{
I Gusti Ayu Krisma Widya Saraswati ${ }^{1}$, I Ketut Suter ${ }^{1 *}$, Anak Agung Istri Wiadnyani ${ }^{1}$ \\ Program Studi Ilmu dan Teknologi Pangan, Fakultas Teknologi Pertanian, Universitas Udayana \\ Kampus Bukit Jimbaran, Badung-Bali \\ *Penulis korespondensi: I Ketut Suter, Email: suter@unud.ac.id
}

\begin{abstract}
This research was to determine the effect of type of solvent and the ratio of material to the solvent with ultrasonication on antioxidant activity of beluntas leaf extract (Pluchea indica Less) and also determine the right type of solvent and the ratio of material to the solvent to extract beluntas leaves with the highest antioxidant activity. The complately Randomized Design (CRD) with 2 factors was used in this study. First factor is the types of solvents with 4 level (aquades, methanol 90\%, ethanol 90\%, acetone 90\%) and second factor is the ratio of materials to solvent with 3 level $(1: 10,1: 15,1: 20)$. The treatment were repeated twice for obtain 24 experimental units. Variables observed were yield, total flavonoids, total tannin, antioxidant activity and $\mathrm{IC}_{50}$. The data were analyzed using variance and if the treatment had a significant effect, on was followed by the Duncan Multiple Range Test. The results showed that the interaction between the types of solvents and the ratio of material to the solvent had a very significant effect ( $\mathrm{P}<0.01)$ on yield, total flavonoids, antioxidant activity, $\mathrm{IC}_{50}$, but the interaction have no real effect on the total tannin only show the very significant effect against solvent type and ratio on total tannin. The results showed that ethanol $90 \%$ with a ratio of 1:20 was the best treatment that produced antioxidant activity of $67.03 \%, \mathrm{IC}_{50}$ of $74.37 \mathrm{ppm}$, total flavonoid of $11.08 \mathrm{mg} \mathrm{QE} / \mathrm{g}$, total tannin of $7.78 \mathrm{mg} \mathrm{TAE} / \mathrm{g}$ and yield of $4.16 \%$.
\end{abstract}

Keywords : beluntas leaf, solvent type, ratio, ultrasonication, antioxidants activity

\section{PENDAHULUAN}

Tanaman Beluntas (Pluchea indica

Less) merupakan salah satu tanaman yang dapat dijumpai di daerah Bali, umumnya tanaman beluntas yaitu pada bagian daun dijadikan sebagai obat tradisional. Adapun manfaat dari daun beluntas yang sering digunakan oleh masyarakat yaitu menghilangkan bau mulut dan bau badan, mengatasai permasalahan pada pencernaan, mengatasi kurang nafsu makan, menghilangkan nyeri pada rematik (Nurhalimah, 2015). Pemanfaatan pada daun beluntas tersebut dikarenakan memiliki komponen bioaktif seperti alkaloid, katekin, saponin, tanin, flavonoid yang berfungsi sebagai zat antioksidan (Rukmiasih, 2011). Manfaat daun beluntas terhadap aktivitas biologis tubuh dapat berperan sebagai antioksidan, antiinflamsi, antipiretik serta berbagai aktivitas famakologi (Sibarani et al., 2013). 
Berdasarkan fungsi serta kandungan yang terdapat pada daun beluntas diperlukan cara untuk mendapatkan komponen bioaktif didalamnya yaitu dengan ekstraksi. Terdapat berbagai jenis metode ekstraksi yang harus disesuaikan dengan sifat bahan dan senyawa yang ingin diperoleh (Sarker, 2006). Metode ekstraksi terbagi atas berbagai jenis yaitu maserasi, perkolasi, sokletasi, destilasi uap, microwave, dan ultrasonikasi. Ultrasonikasi merupakan jenis metode ekstraksi yang menggunakan bantuan gelombang ultrasonik berupa gelombang akustik dengan frekuensi lebih besar dari 20 kHz. Jika energi gelombang ultrasonik tersebut melalui jaringan, maka akan melepaskan energi kalor sehingga terjadi pemanasan yang mengakibatkan suhu jaringan meningkat dan kemudian menimbulkan efek kavitasi, yaitu pembentukan, pertumbuhan dan pecahnya gelembung didalam sebuah cairan sehingga membuat dinding sel dari bahan yang digunakan akan terpecah dan senyawa yang diekstrak mudah keluar (Mason, 1990).

Faktor yang mempengaruhi ekstraksi dengan ultrasonikasi yaitu lama ekstraksi, suhu, ukuran partikel, jenis pelarut, rasio bahan dengan pelarut (Wijngaard et al., 2012). Ekstraksi bertujuan untuk melarutkan senyawa-senyawa yang terdapat dalam jaringan tanaman ke dalam pelarut yang dipakai untuk proses ekstraksi tersebut, sehingga penggunaan pelarut yang tepat menjadi faktor utama dalam ekstraksi
(Sarker, 2006). Efektifitas ekstraksi suatu senyawa oleh jenis pelarut yang digunakan sangat bergantung kepada kelarutan senyawa tersebut dalam pelarut, sesuai dengan prinsip like dissolve like yaitu senyawa akan terlarut pada pelarut dengan sifat yang sama. Jenis pelarut yang memiliki sifat polar diantaranya aquadest, metanol, etanol dan aseton (Sudarmadji et al., 1997).

Penelitian Suryani (2015) terkait ekstraksi daun matoa menggunakan jenis pelarut air, metanol 95\%, etanol 96\% dan aseton $90 \%$ dengan $\mathrm{IC}_{50}$ terendah diperoleh aseton $90 \%$ yaitu 43,52 ppm. Penelitian Kemit (2016) melaporkan pelarut etanol 90\% menghasilkan aktivitas antioksidan sebesar $27,84 \%$ pada ekstrak daun alpukat dibandingkan air, metanol $90 \%$ dan aseton 90\%. Berdasarkan hasil penelitian tersebut, pelarut dengan konsentrasi $90 \%$ mampu menghasilkan senyawa aktivitas antioksidan yang baik dalam ekstraksi. Hal tersebut didukung oleh pernyataan Harborne (1996) memiliki kemampuan yang baik dalam melarutkan senyawa bioaktif yang tergolong dalam antioksidan alami. Penelitian lain seperti Novita et al., (2016) melaporkan bahwa pelarut air mampu menghasilkan total flavonoid lebih tinggi dibandingkan dengan metanol dalam ekstraksi pada beberapa jenis bayam dan sayuran. Penelitian terhadap ekstrak daun beluntas dilakukan oleh Widyawati et al., (2011) memperoleh aktivitas antioksidan pada kisaran 80-90 \% dengan pelarut metanol. 
Berbeda pada penelitian Suryani (2015) melaporkan $\mathrm{IC}_{50}$ terendah pada ekstrak daun matoa terdapat pada aseton $90 \%$ yaitu 43,52 ppm.

Penggunaan pelarut yang memiliki sifat sesuai dengan bahan yang diekstrak tentunya diimbangi dengan penggunaan rasio yang tepat, sehingga melakukan ekstraksi dengan rasio yang tepat akan memaksimalkan penangkapan senyawa bioaktif pada bahan. Anam (2010) melaporkan semakin besar rasio pelarut yang ditambahkan maka tekanan yang diberikan semakin besar sehingga proses difusi yang terjadi semakin besar pula dan menyebabkan cairan sel yang keluar semakin meningkat. Hal tersebut diperkuat dalam penelitian Handayani (2016) melaporkan dalam ekstraksi antioksidan pada daun sirsak menghasilkan nilai $\mathrm{IC}_{50}$ terendah pada rasio bahan dan pelarut 1:10 yaitu 15,58 ppm. Berbeda dengan Rifai (2018) melaporkan pada rasio 1:15 mampu menghasilkan nilai $\mathrm{IC}_{50}$ terendah yaitu 540,95 ppm pada ekstraksi biji alpukat. Penelitian Sumarlan (2018) menunjukkan bahwa pada rasio 1:20 ekstrak buah stroberi mampu menghasilkan $\mathrm{IC}_{50}$ terendah yaitu 13,32 ppm. Peningkatan aktivitas antioksidan terjadi berdasarkan penggunaan pelarut yang tingkat kepolarannya sesuai dengan bahan diiringi dengan rasio yang digunakan semakin tinggi (Rifai, 2018). Berdasarkan hal tersebut perlu dilakukan penelitian mengenai jenis pelarut dan rasio bahan dengan pelarut yang tepat untuk mendapatkan aktivitas antioksidan tertinggi pada ekstrak daun beluntas.

\section{METODE PENELITIAN}

\section{Tempat dan Waktu Penelitian}

Penelitian ini dilaksanakan di Laboratorium Pengolahan Pangan, Laboratorium Analisis Pangan, Laboratorium Rekayasa Proses dan Pengendalian Mutu Fakultas Teknologi Pertanian Universitas Udayana, serta UPT. Laboratorium Biosains Universitas Udayana. Penelitian ini dilakukan pada bulan Desember 2019 sampai dengan bulan Maret 2020.

\section{Bahan dan Alat}

Bahan yang digunakan dalam penelitian ini adalah daun beluntas yang diperoleh dari areal permukiman penduduk Desa Batubulan kangin, Kecamatan Sukawati, Kabupaten Gianyar, Bali. Daun beluntas yang digunakan yaitu yang telah berhasil disortasi berdasarkan kebersihan dan bentuk yang baik. Bahan lain yang digunakan yaitu bahan-bahan kimia seperti aquadest, metanol 90\%, etanol 90\%, aseton 90\%, etanol PA, reagen kuersetin, $\mathrm{AlCl}_{3} 6 \mathrm{H}_{2} \mathrm{O}$, reagen asam tanat, follin dennis, $\mathrm{Na}_{2} \mathrm{CO}_{3}, 2,2$-diphenyl-1-picryl-hydrazyl (DPPH).

Alat-alat yang dipergunakan dalam penelitian ini adalah oven (Blue M), loyang, aluminium foil, blender (Miyako), ayakan 60 mesh (Retsch), erlenmeyer (Iwaki), 
ultrasonikator (bransonic yamato 2200) dengan frekuensi $47 \mathrm{kHz}$, spektrofotometer (Genesys 10S UV-Vis), rotary evaporator vakum (IKA $R V 10$ basic), labu evaporasi (Iwaki), timbangan analitik (Shimadzu ATY224), tip, kertas Whatman No. 1, corong, vortex (Maxi Mix II Type 367000), centrifuge (Damon/IEC Division), pipet tetes, gelas beker (Pyrex), gelas ukur (Herma), spatula, pipet volume (Iwaki), pipet mikro (Accumax PRO), botol kaca berwarna gelap dan alat-alat gelas.

\section{Pelaksanaan Penelitian}

\section{Pembuatan Bubuk Daun Beluntas}

Daun beluntas dalam penelitian ini diperoleh dari areal pemukiman warga yang berada di Desa Batubulan Kangin, Kecamatan Sukawati, Kabupaten Gianyar, Bali. Daun beluntas dibersihkan terlebih dahulu dari kotoran-kotoran yang menempel dengan cara dicuci lalu ditiriskan dan dilakukan pengecilan ukuran dengan tujuan untuk mempermudah pengeringan serta penghancuran. Potongan daun beluntas dioven pada suhu $40^{\circ} \mathrm{C}$ selama 24 jam (Andriani, 2019), setelah daun beluntas kering dilanjutkan dengan diblender hingga halus dan diayak menggunakan ayakan 60 mesh agar mendapatkan bubuk halus dari daun beluntas.

\section{Ekstraksi Bubuk Daun Beluntas dengan Ultrasonikasi}

Proses pembuatan ekstrak daun beluntas yaitu bubuk daun beluntas ditimbang sebanyak $10 \mathrm{~g}$ dengan menggunakan timbangan analitik, kemudian dimasukkan kedalam erlenmeyer. Bahan diberi perlakuan sesuai dengan jenis pelarut yaitu aquades, aseton 90\%, etanol 90\% dan metanol $90 \%$ serta dengan perlakuan rasio bahan dan pelarut 1:10, 1:15 dan 1:20 (b/v). Dilakukan ekstraksi dengan menggunakan ultrasonikasi pada suhu $45^{\circ} \mathrm{C}$ selama 20 menit dengan frekuensi $47 \mathrm{kHz}$. Setelah proses ekstraksi berakhir dilanjutkan dengan penyaringan dengan menggunakan kertas Whatman No. 01. Filtrat yang sudah diperoleh disimpan dalam botol kaca berwarna gelap dan dilanjutkan dengan proses evaporasi menggunakan alat rotary evaporator pada tekanan 241 mbar dan 60 rpm untuk menghasilkan ekstrak kental. Ekstrak kental yang diperoleh ditimbang serta diuji berdasarkan parameter yang diamati.

\section{Rancangan Penelitian dan Analisis Data}

Rancangan yang digunakan pada penelitian ini adalah Rancangan Acak Lengkap (RAL) faktorial dengan dua faktor. Faktor pertama yaitu jenis pelarut (P) dengan 4 taraf sebagai berikut : P1 (aquades), P2 (metanol 90\%), P3 (etanol 90\%), P4 (aseton 90\%). Faktor kedua yaitu rasio bahan dengan pelarut (R) dengan 4 taraf sebagai berikut: R1 (1:10), R2 (1:15), R3 (1:20). Perlakuan diulang 2 kali sehingga diperoleh 24 unit percobaan. Data yang diperoleh dianalisis dengan sidik ragam, apabila perlakuan berpengaruh, maka dilanjutkan dengan uji duncan (Gomez dan Gomez, 1995). 


\section{Parameter yang Diamati}

Parameter yang diamati dalam penelitian ini diantaranya rendemen dengan metode AOAC (AOAC, 1999), total flavonoid dengan metode Spektrofotometri UV-Vis (Rahman, 2006), total tanin dengan metode Spektrofotometri UV-Vis (Suhardi, 1997), aktivitas antioksidan dan $\mathrm{IC}_{50}$ menggunakan metode DPPH dengan Spektrofotometri UV-Vis (Blois (1958) dalam Hanani (2005).

\section{HASIL DAN PEMBAHASAN}

\section{Rendemen Ekstrak Daun Beluntas}

Hasil sidik ragam menunjukkan bahwa interaksi antara jenis pelarut dan rasio bahan dengan pelarut berpengaruh sangat nyata $(\mathrm{P}<0,01)$ terhadap rendemen ekstrak daun beluntas. Hasil analisis rendemen ekstrak daun beluntas dapat dilihat pada Tabel 1. Rendemen ekstrak daun beluntas dalam peneltian ini berkisar antara 3,19\% 14,34 \%. Berdasarkan Tabel 1 dapat dilihat bahwa hasil tertinggi diperoleh jenis pelarut aseton $90 \%$ pada rasio 1:20 sebesar $14,34 \%$ sedangkan hasil terendah terdapat pada jenis pelarut metanol $90 \%$ pada rasio 1:10 dengan hasil 3,19\%. Interaksi yang ditunjukkan antara pelarut aseton 90\% dengan rasio 1:20 menghasilkan rendemen tertinggi ekstrak daun beluntas. Hal tersebut membuktikan penggunaan aseton $90 \%$ dalam rasio 1:20 mampu mengekstrak senyawa bioaktif lebih banyak dibandingkan rasio yang lebih kecil sehingga perlakuan tersebut memperoleh rendemen tertinggi. Menurut Underwood et al., (1990) aseton mampu melarutkan flavonoid, alkaloid serta senyawa bioaktif lainnya karena sifatnya sebagai pelarut polar. Penggunaan pelarut dengan sifat yang sama dengan bahan yang diekstrak serta menggunakan rasio yang tepat, akan memaksimalkan penangkapan senyawa bioaktif. Hal ini didukung dalam pernyataan Benedicta (2016) semakin tinggi rasio yang digunakan dalam pelarut yang kepolarannya sesuai dengan bahan yang diekstrak akan meningkatkan luas kontak antara bahan dengan pelarut yang digunakan, selain itu dengan tinginya rasio bahan dengan pelarut juga mampu meratakan distribusi antara pelarut ke padatan yang nantinya akan meningkatkan rendemen yang dihasilkan.

\section{Total Flavonoid Ekstrak Daun Beluntas}

Hasil sidik ragam menunjukan interaksi jenis pelarut dan rasio bahan dengan pelarut berpengaruh sangat nyata $(\mathrm{P}<0,01)$ terhadap total flavonoid ekstrak daun beluntas. Hasil analisis rata-rata total flavonoid ekstrak daun beluntas dapat dilihat pada Tabel 2. Hasil total flavonoid tertinggi diperoleh pada pelarut etanol $90 \%$ dengan rasio 1:20 sebesar 11,08 $\mathrm{mg} \mathrm{QE} / \mathrm{g}$. Total flavonoid terendah terdapat pada jenis pelarut aquades dengan rasio 1:10 sebesar $4,77 \mathrm{mg} \mathrm{QE} / \mathrm{g}$. 
Tabel 1. Nilai rata-rata rendemen ekstrak daun beluntas (Pluchea indica Less) (\%)

\begin{tabular}{cccc}
\hline \multirow{2}{*}{ Jenis Pelarut } & \multicolumn{3}{c}{ Rasio Bahan dengan Pelarut } \\
\cline { 2 - 4 } & $\mathrm{R} 1(1: 10)$ & $\mathrm{R} 2(1: 15)$ & $\mathrm{R} 3(1: 20)$ \\
\hline P1 & $6,29 \pm 0,01 \mathrm{~b}$ & $6,38 \pm 0,06 \mathrm{~b}$ & $6,57 \pm 0,01 \mathrm{a}$ \\
(Aquades) & $\mathrm{b}$ & $\mathrm{b}$ & $\mathrm{b}$ \\
P2 & $3,19 \pm 0,08 \mathrm{~b}$ & $3,37 \pm 0,08 \mathrm{~b}$ & $5,37 \pm 0,08 \mathrm{a}$ \\
(Metanol 90\%) & $\mathrm{d}$ & $\mathrm{d}$ & $\mathrm{c}$ \\
P3 & $3,76 \pm 0,03 \mathrm{~b}$ & $3,83 \pm 0,01 \mathrm{~b}$ & $4,16 \pm 0,01 \mathrm{a}$ \\
$($ Etanol 90\%) & $\mathrm{c}$ & $\mathrm{c}$ & $\mathrm{d}$ \\
P4 & $7,15 \pm 0,04 \mathrm{c}$ & $7,57 \pm 0,05 \mathrm{~b}$ & $14,34 \pm 0,03 \mathrm{a}$ \\
(Aseton 90\%) & $\mathrm{a}$ & $\mathrm{a}$ & $\mathrm{a}$ \\
\hline
\end{tabular}

Keterangan : Huruf yang sama dibelakang nilai rata-rata pada baris yang sama atau dibawah nilai rata-rata pada kolom yang sama menunjukkan perlakuan tidak berbeda nyata $(\mathrm{P}>0,05)$. Huruf disamping nilai menujukkan notasi pengaruh jenis pelarut terhadap rasio, sedangkan huruf dibawah nilai menunjukkan notasi pengaruh rasio terhadap jenis pelarut.

Tabel 2. Nilai rata-rata total flavonoid ekstrak daun beluntas (Pluchea indica Less) (mgQE/g)

\begin{tabular}{cccc}
\hline \multirow{2}{*}{ Jenis Pelarut } & \multicolumn{3}{c}{ Rasio Bahan dengan Pelarut } \\
\cline { 2 - 4 } & $\mathrm{R} 1(1: 10)$ & $\mathrm{R} 2(1: 15)$ & $\mathrm{R} 3(1: 20)$ \\
\hline P1 & $4,77 \pm 0,01 \mathrm{c}$ & $5,00 \pm 0,04 \mathrm{~b}$ & $5,29 \pm 0,05 \mathrm{a}$ \\
(Aquades) & $\mathrm{d}$ & $\mathrm{d}$ & $\mathrm{d}$ \\
P2 & $8,18 \pm 0,04 \mathrm{~b}$ & $8,30 \pm 0,03 \mathrm{~b}$ & $9,34 \pm 0,06 \mathrm{a}$ \\
(Metanol 90\%) & $\mathrm{b}$ & $\mathrm{b}$ & $\mathrm{b}$ \\
P3 & $10,94 \pm 0,04 \mathrm{a}$ & $11,02 \pm 0,05 \mathrm{a}$ & $11,08 \pm 0,04 \mathrm{a}$ \\
(Etanol 90\%) & $\mathrm{a}$ & $\mathrm{a}$ & $\mathrm{a}$ \\
P4 & $7,43 \pm 0,04 \mathrm{a}$ & $7,68 \pm 0,04 \mathrm{a}$ & $7,61 \pm 0,09 \mathrm{a}$ \\
(Aseton 90\%) & $\mathrm{c}$ & $\mathrm{c}$ & $\mathrm{c}$ \\
\hline
\end{tabular}

Keterangan : Huruf yang sama dibelakang nilai rata-rata pada baris yang sama atau dibawah nilai rata-rata pada kolom yang sama menunjukkan perlakuan tidak berbeda nyata $(P>0,05)$. Huruf disamping nilai menujukkan notasi pengaruh jenis pelarut terhadap rasio, sedangkan huruf dibawah nilai menunjukkan notasi pengaruh rasio terhadap jenis pelarut.

Interaksi antara etanol $90 \%$ dengan rasio 1:20 menghasilkan total flavonoid tertinggi.

Penggunaan pelarut dengan kepolaran yang sesuai dengan bahan serta dimbangi dengan rasio yang tepat akan memperoleh total flavonoid secara maksimum, hal tersebut ditunjukkan oleh perlakuan etanol 90\% dengan rasio 1:20. Hal ini didukung oleh pernyataan dari Chandran et al., (2011) bahwa pelarut etanol menghasilkan total flavonoid lebih tinggi dibandingkan dengan air, metanol dan aseton. Berdasarkan hal tersebut penggunaan etanol dalam rasio yang tepat mampu menghasilkan interaksi yang baik serta total flavonoid yang tinggi dibandingkan pelarut lain. Hasil total flavonoid yang ditunjukkan pelarut etanol 90\% yang menunjukkan bahwa etanol berpengaruh terhadap semua rasio yang diujikan dengan hasil tidak berbeda nyata di setiap rasio. Hal tersebut sesuai dengan pernyataan Delazar (2012) yaitu peningkatan total flavonoid seiring dengan peningkatan rasio diakibatkan oleh semakin banyak pelarut yang digunakan, maka 
penangkapan senyawa target kedalam pelarut dapat berjalan lebih optimal.

\section{Total Tanin Ekstrak Daun Beluntas}

Hasil sidik ragam menunjukkan interaksi antara jenis pelarut dan rasio bahan dengan pelarut berpengaruh tidak nyata $(\mathrm{P}>0,05)$ terhadap total tanin ekstrak daun beluntas, sedangkan pengaruh masing-masing perlakuan jenis pelarut dan rasio bahan dengan pelarut memberikan pengaruh sangat nyata $(\mathrm{P}>0,01)$ terhadap total tanin. Pengaruh jenis pelarut dan rasio bahan dengan pelarut ekstrak daun beluntas dapat dilihat pada Tabel 3. Hasil penelitian menunjukkan bahwa total tanin tertinggi berdasarkan jenis pelarut diperoleh dari pelarut etanol 90\% sebesar 7,55 mg TAE/g sedangkan hasil terendah diperoleh jenis pelarut aquades sebesar 5,42 mg TAE/g. Berdasarkan pengaruh rasio bahan dengan pelarut hasil tertinggi terdapat pada rasio 1:20 dengan total tanin sebesar $6,64 \mathrm{mg}$ $\mathrm{TAE} / \mathrm{g}$ dan hasil terendah terdapat pada rasio 1:10 dengan hasil total tanin sebesar $6,37 \mathrm{mg}$ $\mathrm{TAE} / \mathrm{g}$.

Tabel 3. Nilai rata-rata total tanin ekstrak daun beluntas (Pluchea indica Less) (mgTAE/g)

\begin{tabular}{|c|c|c|c|c|}
\hline \multirow{2}{*}{ Jenis Pelarut } & \multicolumn{3}{|c|}{ Rasio Bahan dengan Pelarut } & \multirow{2}{*}{$\bar{X}$ Jenis Pelarut } \\
\hline & $\mathrm{R} 1(1: 10)$ & $\mathrm{R} 2(1: 15)$ & $\mathrm{R} 3(1: 20)$ & \\
\hline $\begin{array}{c}\text { P1 } \\
\text { (Aquades) }\end{array}$ & $5,33 \pm 0,03$ & $5,40 \pm 0,07$ & $5,53 \pm 0,06$ & $5,42 \pm 0,10 \mathrm{~d}$ \\
\hline $\begin{array}{c}\text { P2 } \\
\text { (Metanol 90\%) }\end{array}$ & $7,18 \pm 0,05$ & $7,24 \pm 0,09$ & $7,38 \pm 0,05$ & $7,27 \pm 0,11 \mathrm{~b}$ \\
\hline $\begin{array}{c}\mathrm{P} 3 \\
(\text { Etanol 90\%) }\end{array}$ & $7,32 \pm 0,05$ & $7,56 \pm 0,07$ & $7,78 \pm 0,06$ & $7,55 \pm 0,21 \mathrm{a}$ \\
\hline $\begin{array}{c}\mathrm{P} 4 \\
\text { (Aseton 90\%) }\end{array}$ & $5,66 \pm 0,03$ & $5,69 \pm 0,04$ & $5,86 \pm 0,06$ & $5,74 \pm 0,10 \mathrm{c}$ \\
\hline $\bar{X}$ Rasio & $\begin{array}{c}6,37 \pm 0,94 \\
\mathrm{c}\end{array}$ & $\begin{array}{c}6,47 \pm 1,00 \\
b\end{array}$ & $\begin{array}{c}6,64 \pm 1,03 \\
a\end{array}$ & \\
\hline $\begin{array}{l}\text { Huruf } \\
\text { rata } \\
\text { disan } \\
\text { dibav }\end{array}$ & i menunju & $\begin{array}{l}\text { rata-rata } p \\
\text { njukkan } p \\
\text { i pengaru } \\
\text { i pengarul }\end{array}$ & $\begin{array}{l}\text { ang sama a } \\
\text { idak berbeda } \\
\text { rut terhadap } \\
\text { adap jenis pe }\end{array}$ & $\begin{array}{l}\text { awah nilai rata- } \\
P>0,05) \text {. Huruf } \\
\text { edangkan huruf }\end{array}$ \\
\hline
\end{tabular}

Berdasarkan hasil pada perlakuan jenis pelarut dengan hasil tertinggi yang diperoleh jenis pelarut etanol 90\% menunjukkan bahwa etanol efektif untuk mengekstrak tanin pada ekstrak daun beluntas. Menurut Pandey dan Shalini (2014) etanol mampu melarutkan senyawa tanin lebih baik dibandingkan pelarut lain. Tingkat kepolaran pelarut etanol sesuai dengan senyawa tanin pada daun beluntas sehingga etanol mampu menghasilkan total tanin lebih tinggi dibandingkan pelarut aquades, metanol 90\% dan aseton 90\%. Perlakuan rasio bahan dengan pelarut menunjukkan semakin besar rasio akan menghasilkan total tanin semakin meningkat. Hal tersebut sesuai dengan yang dilaporkan oleh Delazar et al., (2012) bahwa semakin banyak penambahan pelarut maka 
penangkapan senyawa target akan lebih optimal

\section{Aktivitas Antioksidan Ekstrak Daun Beluntas}

Hasil sidik ragam menunjukan interaksi dari jenis pelarut dan rasio bahan dengan pelarut berpengaruh sangat nyata $(\mathrm{P}<0,01)$ terhadap aktivitas antioksidan ekstrak daun beluntas. Hasil analisis ratarata aktivitas antioksidan ekstrak daun beluntas dapat dilihat pada Tabel 4 . Berdasarkan tabel hasil tersebut aktivitas antioksidan ekstrak daun beluntas tertinggi diperoleh pada perlakuan etanol 90\% dengan rasio 1:20 sebesar 67,03\%. Aktivitas antioksidan terendah terdapat pada pelarut aquades dengan rasio 1:10 sebesar 37,08\%, hasil tersebut tidak berbeda nyata pada perlakuan pelarut aquades rasio 1:15 sebesar $37,64 \%$.

Perlakuan etanol $90 \%$ dengan rasio 1:20 menjadi perlakuan yang tepat untuk mendapatkan aktivitas antioksidan yang maksimal dari ekstrak daun beluntas karena penggunaan pelarut dengan tingkat kepolaran yang sesuai serta rasio bahan dengan pelarut yang tepat akan menghasilkan aktivitas antioksidan yang maksimal. Hal tersebut ditunjukkan oleh etanol $90 \%$ dengan konstanta dielektrikum 24,30 mampu mendekati kepolaran dari ekstrak daun beluntas (Sudarmadji et al., 2003). Perlakuan etanol $90 \%$ menunjukkan nilai aktivitas antioksidan yang meningkat disetiap rasio yang diujikan. Hal tersebut sesuai dengan pernyataan Anam (2010) yaitu jika jumlah pelarut etanol semakin ditingkatkan maka kontak antara bahan dengan pelarut etanol akan semakin besar sehingga hasil ekstraksi senyawa bioaktif akan semakin maksimal. Hasil aktivitas antioksidan dalam penelitian ekstrak daun beluntas ini menunjukkan hasil yang sejalan dengan total flavonoid dan total tanin dengan hasil tertinggi pada pelarut etanol $90 \%$ dan semakin meningkat rasio yang digunakan. Hal tersebut sesuai dengan penelitian Pujimulyani et al., (2010) bahwa terdapat keterkaitan antara total flavonoid serta tanin terhadap hasil aktivitas antioksidan yang dihasilkan.

\section{IC $_{50}$ Ekstrak Daun Beluntas}

Hasil sidik ragam menunjukan interaksi dari jenis pelarut dan rasio bahan dengan pelarut berpengaruh sangat nyata $(\mathrm{P}<0,01)$ terhadap kadar aktivitas antioksidan berdasarkan nilai $\mathrm{IC}_{50}$ ekstrak daun beluntas. Hasil analisis rata-rata $\mathrm{IC}_{50}$ ekstrak daun beluntas dapat dilihat pada Tabel 5 . Berdasarkan tabel rata-rata $\mathrm{IC}_{50}$ menunjukkan bahwa hasil terendah diperoleh pada perlakuan jenis pelarut etanol $90 \%$ dengan rasio bahan dengan pelarut 1:20 sebesar $74,37 \mathrm{ppm}$ dan nilai $\mathrm{IC}_{50}$ tertinggi terdapat pada perlakuan jenis pelarut aquades dengan rasio bahan dengan pelarut 1:10 sebesar $142,28 \mathrm{ppm}$. 
Tabel 4. Nilai rata-rata aktivitas antioksidan ekstrak daun beluntas (Pluchea indica Less) (\%)

\begin{tabular}{cccc}
\hline \multirow{2}{*}{ Jenis Pelarut } & \multicolumn{3}{c}{ Rasio Bahan dengan Pelarut } \\
\cline { 2 - 4 } & $\mathrm{R} 1(1: 10)$ & $\mathrm{R} 2(1: 15)$ & $\mathrm{R} 3(1: 20)$ \\
\hline P1 & $37,08 \pm 0,23 \mathrm{~b}$ & $37,64 \pm 0,10 \mathrm{~b}$ & $44,03 \pm 0,29 \mathrm{a}$ \\
(Aquades) & $\mathrm{d}$ & $\mathrm{d}$ & $\mathrm{d}$ \\
P2 & $50,89 \pm 0,31 \mathrm{~b}$ & $51,77 \pm 0,24 \mathrm{~b}$ & $55,94 \pm 0,13 \mathrm{a}$ \\
$($ Metanol 90\%) & $\mathrm{b}$ & $\mathrm{c}$ & $\mathrm{b}$ \\
P3 & $56,89 \pm 0,28 \mathrm{~b}$ & $66,22 \pm 0,78 \mathrm{a}$ & $67,03 \pm 0,20 \mathrm{a}$ \\
$($ Etano1 90\%) & $\mathrm{a}$ & $\mathrm{a}$ & $\mathrm{a}$ \\
P4 & $46,07 \pm 0,38 \mathrm{c}$ & $55,56 \pm 0,16 \mathrm{a}$ & $52,37 \pm 0,42 \mathrm{~b}$ \\
$($ Aseton 90\%) & $\mathrm{c}$ & $\mathrm{b}$ & $\mathrm{c}$ \\
\hline
\end{tabular}

Keterangan: Huruf yang sama dibelakang nilai rata-rata pada baris yang sama atau dibawah nilai rata-rata pada kolom yang sama menunjukkan perlakuan tidak berbeda nyata $(\mathrm{P}>0,05)$. Huruf disamping nilai menujukkan notasi pengaruh jenis pelarut terhadap rasio, sedangkan huruf dibawah nilai menunjukkan notasi pengaruh rasio terhadap jenis pelarut.

Tabel 5. Nilai rata-rata IC50 ekstrak daun beluntas (Pluchea indica Less) (ppm)

\begin{tabular}{cccc}
\hline Jenis Pelarut & $\mathrm{R} 1(1: 10)$ & Rasio Bahan dengan Pelarut \\
\hline P1 & $142,28 \pm 1,39 \mathrm{a}$ & $138,54 \pm 0,19 \mathrm{a}$ & $114,72 \pm 1,76 \mathrm{~b}$ \\
(Aquades) & $\mathrm{a}$ & $\mathrm{a}$ & $\mathrm{a}$ \\
P2 & $105,78 \pm 1,41 \mathrm{a}$ & $102,67 \pm 1,21 \mathrm{a}$ & $84,74 \pm 1,76 \mathrm{~b}$ \\
(Metanol 90\%) & $\mathrm{b}$ & $\mathrm{b}$ & $\mathrm{b}$ \\
P3 & $87,78 \pm 1,71 \mathrm{a}$ & $78,33 \pm 0,20 \mathrm{~b}$ & $74,37 \pm 1,46 \mathrm{~b}$ \\
$($ Etanol 90\%) & $\mathrm{c}$ & $\mathrm{d}$ & $\mathrm{c}$ \\
P4 & $107,41 \pm 0,18 \mathrm{a}$ & $90,41 \pm 1,12 \mathrm{~b}$ & $85,46 \pm 0,46 \mathrm{c}$ \\
(Aseton 90\%) & $\mathrm{b}$ & $\mathrm{b}$ & $\mathrm{b}$ \\
\hline
\end{tabular}

Keterangan: Huruf yang sama dibelakang nilai rata-rata pada baris yang sama atau dibawah nilai rata rata pada kolom yang sama menunjukkan perlakuan tidak berbeda nyata $(\mathrm{P}>0,05)$. Huruf disamping nilai menujukkan notasi pengaruh jenis pelarut terhadap rasio, sedangkan huruf dibawah nilai menunjukkan notasi pengaruh rasio terhadap jenis pelarut.

Interaksi yang ditujukkan etanol $90 \%$ dengan rasio 1:20 mampu menghasilkan nilai $\mathrm{IC}_{50}$ terendah. $\mathrm{IC}_{50}$ memiliki arti konsentrasi yang mampu meredam 50\% radikal bebas DPPH (Hukmah, 2007). Interaksi yang ditunjukkan perlakuan etanol 90\% dengan rasio 1:20 berbanding lurus dengan hasil pada total flavonoid, serta masing-masing perlakuan jenis pelarut serta rasio bahan dengan pelarut tertinggi pada total tanin. Etanol 90\% memilik sifat mampu mengekstrak senyawa bioaktif yang tergolong antioksidan alami seperti flavonoid dan tanin (Shahidi et al., 1995). Berdasarkan sifat etanol tersebut, penggunaannya dalam rasio yang semakin tinggi akan menghasilkan nilai $\mathrm{IC}_{50}$ semakin rendah. Hal ini sesuai dengan pernyataan Siregar (2005) semakin banyak pelarut yang digunakan akan besar kemampuan pelarut tersebut melarutkan bahan sehingga komponen bioaktif bahan yang dapat terekstrak secara maksimum oleh pelarut. Molyneux (2004) melaporkan bahwa semakin rendah nilai $\mathrm{IC}_{50}$ maka aktivitas antioksidan akan semakin tinggi. Hal 
tersebut sesuai dengan penelitian ekstrak daun beluntas ini dengan hasil tertinggi pada aktivitas antioksidan yaitu perlakuan etanol 90\% dengan rasio bahan dengan pelarut 1:20 sebesar $67,03 \%$ dan pada nilai $\mathrm{IC}_{50}$ terendah sebesar 74,37 ppm dengan hasil ekstrak daun beluntas tersebut maka tergolong dalam aktivitas antioksidan yang kuat.

\section{KESIMPULAN DAN SARAN}

\section{Kesimpulan}

Interaksi jenis pelarut dan rasio bahan dengan pelarut pada ekstraksi daun beluntas (Pluchea indica Less) pada metode ultrasonikasi berpengaruh sangat nyata terhadap parameter rendemen, total flavonoid, aktivitas antioksidan dan $\mathrm{IC}_{50}$. Perlakuan terbaik yang dapat digunakan untuk mengekstrak dan beluntas yaitu dengan jenis pelarut etanol $90 \%$ pada rasio bahan dengan pelarut 1:20. Perlakuan tersebut mampu menghasilkan aktivitas antioksidan sebesar $67,03 \%, \mathrm{IC}_{50}$ sebesar $74,37 \mathrm{ppm}$, total flavonoid 11,08 mg QE/g, total tanin 7,78 $\mathrm{mg} \mathrm{TAE} / \mathrm{g}$ dan rendemen $4,16 \%$.

\section{Saran}

Daun beluntas memiliki potensi sebagai sumber aktivitas antioksidan yang termasuk dalam golongan kuat dengan dilakukan ekstraksi pada metode ultrasonkasi menggunakan jenis pelarut etanol $90 \%$ serta rasio bahan dengan pelarut sebesar 1:20. Daun beluntas dengan potensinya sebagai antioksidan dapat dikembangkan menjadi pangan fungsional sehingga pemanfaatanya menjadi lebih luas.

\section{DAFTAR PUSTAKA}

Anam, C. 2010. Ekstraksi oleoresin jahe (Zingiber officinale) kajian dari ukuran bahan, pelarut, waktu dan suhu. Jurnal Pertanian MAPETA. 2:72-144.

AOAC. 1999. Official Method Of Analysis Of Association Official Analytical Chemical. AOAC Inc, Washington.

Benedicta, N., Z. Sudaryanto, S. Nurjanah, A. Widyasanti, dan S. Putri,. 2016. Pengaruh rasio dengan pelarut terhadap rendemen dan mutu minyak melati (Jasminum sambac) menggunakan metode ekstraksi pelarut menguap (Solvent Extraction). Jurnal Teknotan. 10(2):44-50.

Blois, M.S. 1958. Antioxidants determination by the use of a stable free radical. Journal Nature. 181 (4617):1199 - 1200.

Chandran, R., P. Thangaraj, S. Shanmugam, S. Thankarajan, and A. C. Karuppusamy. 2011. Antioksidant and antiinflammatory potential of Monochoria Vaginalis (Burm. F.) C. Presl. : a wild edible plant. Journal of Food Biochemistry.

Delazar, A., L. Nahar., S. Hamedeyaz, and S.D. Satyajit. 2012. Microwave-assited extraction in natural products isolation natural products isolation, methods in molecular biology. Springer Science, New York. 864:215-218.

Hanani., M. A. dan R. Sekarini. 2005. Identifikasi senyawa antioksidan dalam spons Callyspongia sp. dari kepulauan seribu. Majalah Ilmu Kefarmasian. 2(3):127-133.

Handayani,. S. dan Feronika. 2016. Ekstraksi antioksidan daun sirsak metode ultrasonic bath (kajian rasio bahan : pelarut dan lama ekstraksi). Jurnal Pangan Dan Agroindustri . 4(1):262-272.

Harborne, J.B. 1996. Metode Fitokimia: Cara Menganalisis Tanaman. Edisi Ke 2. Penerjemah K. Padmawinata. Institut Teknologi Bandung, Bandung.

Hukmah, S. 2007. Aktivtas Antioksidan Katekin dari The Hijau Hasil Ekstraksi 
dengan Variasi Pelarut dan Suhu. Skripsi S1. Tidak dipublikasi. Universitas Islam Negeri Malang, Malang

Kemit, N. 2016. Pengaruh Jenis Pelarut dan Waktu Ekstraksi Terhadap Kandungan Senyawa Flavonoid dan Aktivitas Antioksidan Ekstrak Daun Alpukat (Persea americana Mill.). Skripsi S1. Tidak dipublikasi. Fakultas Teknologi Pertanian Universitas Udayana, Bali.

Mason, J.P. 1990. Applied Sonochemistry: The Uses Of Power Ultrasonic In Chemistry And Processing. Weinheim (De): Wiley- Vch Verlag Gmbh And Co.

Molyneux, P. 2004. The use of the stable free radical diphenylpicrylhydrazyl (dpph) for estimsting antioxidant activity. Journal of Science and Technology. 26:2111-219.

Novita, M., M. I. Sulaiman, dan S. Yura. 2016. Pengaruh jenis pelarut terhadap aktivitas antioksidan dan kandungan fenol beberapa jenis bayam dan sayuran lain. Jurnal Ilmiah Mahasiswa Pertanian Unsyiah. 1(1):935-940.

Nurhalimah, H., N. Wijayanti, dan T. D. Widyaningsih. 2015. Efek antidiare ekstrak daun beluntas (Pluchea indica Less.) terhadap mencit jantan yang diinduksu bakteri Salmonella typhimurium. Jurnal Pangan dan Agroindustri. 3(3):1083-1094.

Pandey, A. and T. Shalini. 2014. Concept of standarization, extraction and pree phytochemical screening strategies for herbal drug. Journal of Pharmacognosy and Phytochemistry. 2(5):115-119.

Pujimulyani, D., S. Raharjo, Y. Marsono, dan U. Santoso. 2010. Aktivitas antioksidan dan kadar senyawa fenolik pada kunir putih (Curcuma manga Val.) segar dan setelah blanching. Jurnal AGRITECH. 30(2):68-74.

Rahman, A.R. dan Utari. 2006. Aktivitas antioksidan, kandungan fenolat total dan kandungan flavonoid total ekstrak etil asetat buah mengkudu serta fraksifraksinya. Majalah Farmasi Indonesia. 17(3):136-142.

Rifai, G., I.W. Rai Widarta, dan K.A. Nocianitri. 2018. Pengaruh jenis pelarut dan rasio bahan dengan pelarut terhadap kandungan senyawa fenolik dan aktivitas antioksidan ekstrak biji alpukat (Persea americana Mill.). Jurnal ITEPA. 7(2):2232.
Rukmiasih. 2011. Penurunan Bau Amis (OffOdor) Daging Itik Lokal dengan Pemberian Daun Beluntas (Pluchea indica Less.) dalam Pakan dan Dampaknya Terhadap Performa. Disertasi. Tidak dipublikasi. Program Pascasarjana. Institut Pertanian Bogor, Bogor.

Sarker., L. Z and G. Ai. 2006. Natural Products Isolation. In: Sarker Sd, Latif Z, \& Gray Ai, Editors. Natural Products Isolation. 2nd Ed. Totowa (New Jersey). Humana Press Inc. p.6-10, 18.

Shahidi, F. and M. Naczk. 1995. Phenolics in Food and Nutraceuticals. CRC Press LLC. New.

Sibarani, V. R., P. M Worwor, dan Awaloei. 2013. Uji efek analgesik ekstrak daun beluntas (Pluchea indica 1.) pada mencit (musmusculus). Jurnal E-Biomedik (Ebm). 1(1):621-628.

Siregar, E.D.M. 2005. Perlakuan Jenis Pakan Alami pada Daun Sirsak dan Teh. Skripsi S1. Tidak dipublikasi. Institut Pertanian Bogor, Bogor.

Sudarmadji, S., B. Haryono, dan Suharji. 1997. Prosedur Analisi untuk Bahan Makanan dan Pertanian. Penerbit Liberti, Yogyakarta.

Sudarmadji, S., Haryadi, dan D. Suhardi. 2003. Prosedur Analisis Untuk Bahan Makanan dan Pertanian. Penerbit Liberti, Yogyakarta.

Suhardi. 1997. Analisis senyawa polifenol produk buah-buahan dan sayuran.. Lab. Kimia-Biokimia Pengolahan Fakultas Teknologi Pertanian. Universitas Gadjah Mada, Yogyakarta. Vol 3.

Sumarlan, S., B. Susilo, A. Mustofa, dan M. Mu'nim. 2018. Ekstraksi senyawa antioksidan dari buah strawberry (Fragaria $x$ ananassa) dengan menggunakan metode microwave assisted extraction (kajian waktu ekstraksi dan rasio bahan dengan pelarut). Jurnal Keteknikan Pertanian Tropis dan Biosistem. 6:40-51.

Suryani, N. C. 2015. Pengaruh Jenis Pelarut Terhadap Kandungan Total Flavonoid dan Aktivitas Antioksidan Ekstrak Daun Matoa (Pometia pinnata). Skripsi S1. Tidak dipublikasi. Universitas Udayana. Bali. 
Underwood, A., L. Ficia, dan A.R. Day. 1990. Analisis Kimia Kuantitatif Edisi Kelima. Penerbit Erlangga, Jakarta.

Widyawati, P., H. Wijaya, P. Hardjosworo, dan D. Sajuthi. 2011. Evaluasi aktivitas antioksidatif ekstrak daun beluntas (Pluchea indica) berdasarkan perbedaan ruas daun. Jurnal Teknologi Pangan. 5(1):1-14.

Wijngaard, H., M. B Hossain, D. K Rai, and N. Brunton. 2012. Techniques to extract bioactive compounds from food byproducts of plant origin. Journal Food Research International. 46:505-513. 